\title{
Improving Kindergarten Pupils' Speaking Skills Through the Storytelling
}

\author{
Ike Aprillina ${ }^{1 *}$, Baginda Simaibang ${ }^{2}$, Mulyadi $^{2}$ \\ ${ }^{1}$ Paramount School Palembang \\ ${ }^{2}$ Universitas PGRI Palembang \\ *Corresponding author. Email: ikeaprillina@gmail.com
}

\begin{abstract}
The objective of this research is to investigate the improvement of kindergarten pupils' speaking skills through the storytelling at Palembang Paramount School. The data were collected through observing, oral test, and interview result and data analysis by using qualitative and quantitative. The result of the study showed that the technique of storytelling in the class effectively improved pupils' speaking skills. The results show that there was a development in pupils' ability in speaking skills. From the data analysis, it was found that the score obtained in cycle 1 was 50.2 (Poor), then in the second cycle the score increased to be 66.56 (Fair). Then, there was a very high increase in the third cycle, which was 87.88 (Excellent). In conclusion, the application of storytelling could improve pupils' speaking skills of kindergarten in Paramount school.
\end{abstract}

Keywords: Storytelling, Speaking Skills, Kindergarten Pupils

\section{INTRODUCTION}

English is a global language that is spoken as a first language as well as a second or foreign language in many countries. It is taught in almost every country's school system, and the fact that English is now the most widely spoken language on the planet is undeniable [1]. English is the universal language in all areas of international life, including commerce, research, diplomacy, education, and travel, and has been for many years.

In the researcher class, pupils did not want to speak English because they were embarrassed or not confident. There were also other factors, namely lack of training for pupils to speak English at home. It made them not available or could not use English for daily conversations at school. Then, they only imitated or repeated what the teacher/researcher says. This was what the underlies pupils to be accustomed or familiar in English.

For this matter, the teachers should create the situation and learning activity more active and interesting for pupils to learn English. "When possible, make learning fun, interesting and rewarding" [7]. From the background that has been written, It meant that there were some important problems to be solved which existed in the classroom which involved the learning processes, the students, and the teaching technique.
Researchers agree that storytelling is one of the most powerful ways to teach speaking. Storytelling is one tool for improving communicative skills in a real-life language context [6].

The problems of this research may thus be formulated as follows, based on the problem's context and identification: "How does the use of storytelling techniques boost the speaking ability of kindergarten students at Palembang Paramount School?" The study's goal was to see if using the Storytelling technique could develop kindergarten students' speaking skills at Palembang Paramount School, based on the research question.

\section{Theoretical Review}

\section{Concept of Kindergarten Pupils}

Early childhood education, according to the national education framework, is an attempt made to show children from birth until the age of six years by offering educational stimulation to aid physical and spiritual growth and development so that children are ready to enter further education [8].

PAUD (Pendidikan Anak Usia Dini, lit. Early Age Education) encompasses pre-school education in Indonesia, which includes Taman Bermain (playgroup) and Taman Kanak-Kanak (kindergarten, abbreviated TK). PAUD is overseen and covered by the Directorate of Early Childhood Education Development (Direktorat Pengembangan Pendidikan Anak Usia Dini). They have 
been attending Taman Kanak-Kanak since they were four years old. The classes in most TKs are divided into two grades: A and B, which are referred to as kelas nol kecil (little zero grade) and kelas nol besar (big zero grade) informally.

\section{Concept of Speaking}

The most significant skill that children requirement for school, to think and learn, comprehend and convey, peruse and compose, ask and answer inquiries, arrange, reason and issue illuminate, express their idea and emotions, set up companionship, co-work with others, and their behavior is spoken language. Spoken language is the essential human communication and the important strategy for instructing from early childhood through to higher education [5].

Speaking skill is one of language skills after listening skill [3]. Speaking is the skill of conveying messages through spoken language to others. Speaking is identical to the use of spoken language by Tarigan [3], [10], [11], [12].

\section{Concept of Storytelling}

The essence of storytelling is communication. Storytelling is both a form of communication and a method of communication growth. Children's needs will be identified and an emotional connection with the storyteller will be established through intense contact. [4].

Storytelling is the oldest method of instruction. It helped children find answers to the biggest questions about conception, existence, and the afterlife, forming human societies in the process. Stories teach us, mold us, influence us, and build us. While not every culture on the planet is literate, every culture has a tale to tell. [2].

Many ways can be done to develop the development of children's language, one of which is by storytelling activities. Through this storytelling, process communication can be established between storyteller with the audience, in this case between teacher and pupil.

\section{METHODS}

This form of classroom action research was used to conduct this study. Classroom action research (CAR) is action research carried out directly by teachers/researchers to enhance the learning process for which they are responsible. Classroom action research is one of the ways educators can enhance the consistency of their positions and responsibilities as educators in learning management.

The key goal of classroom action research is to develop learning habits in the classroom. As a teacher/storyteller, the researcher was actively active in the preparation, action, assessment, and reflection phases of this activity. There were four steps in doing classroom action research planning research, acting, observing, and reflecting. Those steps have done in every cycle of research. Many ways can be done to develop the development of children's language, one of which is by storytelling activities. Through this storytelling, process communication can be established between storytellers with the audience, in this case between teacher and pupil. Such communication can improve the quality of interaction between teachers and pupil. When the interaction is intertwined, it can influence children's speaking ability.

The researcher used 3 ways in teaching speaking by using storytelling:

1. Using pictures/flash cards/book as media

2. Using puppets/dolls or costumes as media

3. Using videos as media

Preparation before the storytelling event starts, during the storytelling process, and after the operation is completed are the three phases of storytelling.

\section{RESULTS AND DISCUSSION}

\section{A. Result}

The using of the storytelling technique in teaching English made good improvement to the pupils' speaking skill. The pupils became better from the first cycle to the next cycle.

In the summary table of pupils improvement, it can be seen that the value obtained in cycle 1 was 50.2 (Poor Grade), then in the second cycle the score increased to be 66.56 (Fair Grade), meaning that there was an increase of 16.36 in this second cycle. Then, there was a very high increase in the third cycle, which was 87.88 (Excellent Grade) from the second cycle there is an increase of 21.32. This shows that the pupils' speaking skills improved with the use of storytelling techniques.

The following is a table of the summary results of the observation assessment cycle 1,2 and 3 which describes pupils' learning achievement obtained from 3 (three) observations: 1. Teaching-learning process, 2. Pupils 'Activeness, and 3. Pupils' Capability in answering the questions. 
Table 1 Summary of Pupils' Improvement

\begin{tabular}{cccc}
\hline OBSERVATION & CYCLE I & CYCLE II & CYCLE III \\
Teaching Learning Process & 66,60 & 73 & 89 \\
Pupils' Activeness & 43,15 & 57,90 & 87,40 \\
Pupils' Capability Answering Question & 40,85 & 68,80 & 87,25 \\
Mean & $\underline{150,6}$ & $\underline{199,7}=$ & $\underline{263,65}=$ \\
& 3 & 3 & $\mathbf{8 7 , 8 8}$ \\
\hline
\end{tabular}

\section{B. Discussion}

Teachers should perform classroom action research to observe and focus on their teaching-learning process. Furthermore, it can boost students' interest because the learning process is still changing with the passage of time, and it can keep them from being bored with the learning activity.

Related to the findings, teaching speaking by using the application of storytelling could improve kindergarten pupils' speaking skills. They are described as follows: application of storytelling in learning English can run well, it can be seen from the teacher's ability to manage learning that has increased from cycle I, II, and cycle III. This has a positive impact on the progress of pupils' academic abilities, namely those who can indicated by the increase in the percentage on each observation sheet of the teacher's ability to manage learning done by the collaboration teacher, namely from cycle I and cycle II and cycle III are as follows:

a. For the result score of the observation sheet of teaching and learning process there is significant improvement : cycle I: 66.6 (fair grade), cycle II: 73 (good grade) and cycle III: 89 (excellent grade),

b. For the result of the observation sheet of pupils' activeness and comprehension there is also an improvement from each cycle: cycle I: 43,15 (poor grade), cycle II: 57,9 (fair grade), and the cycle III: 87,4 (excellent grade),

c. These are the result of pupil's capability in answering the questions given orally from each cycle: cycle I: 40,85 (poor grade), cycle II: 68,8 (fair grade), cycle III: 87,25 (excellent grade).

According to Peck (in Napitupulu et.al, 2019) \& [9] that using the storytelling method learners exposed to new vocabulary, real-context, expressions and pronunciation to be used in oral production. Based on the result above, using storytelling as a method or strategy for teaching speaking especially English we can achieve the teaching-learning goal optimally.

\section{CONCLUSION}

In line with the findings as presented in previous chapter the conclusion of this study is stated as follows: the application of storytelling could improve kindergarten pupils' speaking skills at Palembang Paramount School.

Based on the result of the study, the researcher has some suggestions to the following parties.

\section{The Pupils}

The result of the study indicates that the speaking skill of the pupils of kindergarten of Palembang (K2.A class) is improved. The researcher hoped that the pupils can be more increase their ability. The pupils need to enrich their experiences in speaking English mastery. They also need to increase their motivation and interest to speak well in order to be more advance than before.

\section{The Teachers}

Classroom action study is a method for teachers to address teaching and learning challenges in the classroom. If a teacher wants to boost his or her quality and gain more teaching experience, he or she must pay attention to his or her actions. Furthermore, this classroom action research can assist students in coping with their learning and increasing their academic competence.

For the teacher, it is hoped that this research can encourage them to consider a better and attractive way in teaching English to improve the pupils' skill in speaking. The teacher also can apply this storytelling as a method to develop the pupils' ability, take the interesting topic or story that will not make the pupils 
bored. Teachers should develop a variety form of reward given to pupils. Rewards can be either just clapping or can use student achievement points in learning so that pupils are more motivated to speak English.

It is hoped that the use of storytelling learning techniques can continue to be used in the learning process in the classroom not only in English lessons but also in other subjects.

\section{Other Researchers}

There are still many aspects which can be analyzed about speaking and other skills of English concerned with English language. Finally, other researchers can make this research as a reference and also it may be used as information to conduct further researches.

\section{REFERENCES}

[1] Crystal, D. English as a Global Language. New York: Cambridge University Press. 2012.

[2] Friday, Matthew James. "Why Storytelling in the Classroom Matters". Edutopia.org. https://www.edutopia.org/blog/storytelling-in-theclassroom-matters-matthew-friday. (accessed January $\left.5^{\text {th }}, 2021\right)$.

[3] Jahrir, A. S. Membaca. Pasuruan: Qiara Media. 2020.

[4] Kurniawan. Kreatif Mendongeng Untuk Kecerdasan Jamak Anak. Jakarta: Kencana. 2016.

[5] Locke, A. Teaching and Speaking. London: Bloomsbury Publishing. 2013.

[6] Napitupulu, Selviana et al. Research Metodology in Linguistics and Education. Yogyakarta: Deepublish. 2019.

[7] Race, Phil and Nick Packard. 2000 Tips for Teachers. New York: Routledge. 2013.

[8] Undang-undang Republik Indonesia Nomor 20 Tahun 2003. Lembaran Negara Republik Indonesia Tahun 2003: Jakarta. 2003.

[9] Syafryadin, H., \& Salniwati, A. R. A. P. Digital Storytelling Implementation for Enhancing Students' Speaking Ability in Various Text Genres. International Journal of Recent Technology and Engineering (IJRTE). 8(4), 31473151. 2019

[10] Syafryadin, S. Students' Strategies in Learning Speaking: Experience of Two Indonesian Schools. Vision: Journal for Language and Foreign Language Learning, 9(1), 33-46. 2020

[11] Syafryadin, S., Martina, F., \& Salniwati, S. (2020). Compensation strategies in speaking activities for non-English department students: poor and competent speakers. JEES (Journal of English Educators Society), 5(2), 109-116.

[12] Syafryadin, S. (2020). The Effect of Talking Chips Technique Toward the Improvement of Students' Speaking Achievement at one of the Senior High Schools in Bandung. Linguists: Journal of Linguistics and Language Teaching, 6(2), 1-13. 